Pak. j. sci. ind. res. Ser. B: biol. sci. 2017 60(2) 92-101

\title{
Influence of Carrot Pulp Fortified with Different Concentrations of Apple Pulp on Blended Jam
}

\author{
Shermat Ullah ${ }^{\mathrm{a}}$, Arsalan Khan ${ }^{\mathrm{b}}$, Muhammad Ayub ${ }^{\mathrm{a}}$, Ishfaq Ahmed ${ }^{\mathrm{c} *}$, \\ Baber Shamrez ${ }^{\text {b }}$ and Mati Ullah Khan ${ }^{a}$ \\ ${ }^{a}$ Department of Food Science and Technology, The University of Agriculture Peshawar, Pakistan \\ ${ }^{\mathrm{b}}$ Agriculture Research Institute, Tarnab Farm, Peshawar, Pakistan \\ 'Ocean University of China, Qingdao, P. R. China
}

(received November 13, 2015; revised October 6, 2016; accepted November 7, 2016)

\begin{abstract}
The aim of this study was to evaluate various combination and effect of storage period on the quality of carrot apple blended jam at ambient temperature $\left(18-25{ }^{\circ} \mathrm{C}\right)$. The treatments were $\mathrm{CA}_{0}, \mathrm{CA}_{1}$, $\mathrm{CA}_{2}, \mathrm{CA}_{3}, \mathrm{CA}_{4}$ and $\mathrm{CA}_{5}$. All the treatments were examined for physicochemical properties i.e., total soluble solids (TSS), $\mathrm{pH}$, reducing sugars (\%), percent acidity, non-reducing sugars (\%), ascorbic acid (mg/100 g), as well as for sensory properties at fifteen days interval for a total storage period of 90 days. Significant increase $(\mathrm{P}<0.05)$ were examined in TSS $\left(67.45-70.40^{\circ}\right.$ brix $)$, acidity $(0.64-0.80)$ and reducing sugars (16.64-27.78). While, significant decrease $(\mathrm{P}<0.05)$ were examined in $\mathrm{pH}(3.63-3.44)$, non reducing sugars (45.04-27.69), ascorbic acid (7.81-5.52 mg/100 g), colour (7.33-4.35), taste (7.40-4.12), texture (7.224.06) and overall acceptability (7.36-4.14). Statistical results concluded that treatment and storage has a significant effect on the quality and stability of carrot pulp and apple pulp blend jam. Results revealed that good quality jam could be prepared with equal amount of carrot and apple pulp, which showed with minimum damage to physiochemical and sensory attributes among the other treatment even after 90 days of storage.
\end{abstract}

Keywords: carrot, apple, blended jam, storage, physicochemical properties, sensory properties

\section{Introduction}

Carrot (Daucus carota L.) is a winter vegetable cultivated for its edible roots throughout the world. Due to its nutritional value it has much importance in our diet (Chaturvedi et al., 2013). It is a low price and easily available resource of $\beta$-carotene. Among vegetables, carrots have greater amount of sugar, indicated by its sweetness (Lingappa and Naik, 1997). In Pakistan, carrot is cultivated on a large area of 13,900 hectares and its production is 242,300 tonnes. Production wise carrot is ranked third among vegetables. About 17.5 tonnes/hectare carrots are produced in Pakistan, which is very less as compared to other countries like Belgium (47.64 tonnes/hectare), United Kingdom (44.28 tonnes/ hectare) and Denmark (44.29 tonnes/hectare) (Samie et al., 2010). However, $73 \mathrm{~kg}$ per capita per year is sufficient to fulfill human vitamin $\mathrm{A}$ and $\mathrm{C}$ requirements (Ali and Abedullah, 2002).

Carrot contains moisture content in between 86 to $89 \%$. Chemically, carrot contains $0.2 \%$ fat, $0.9 \%$ protein, $1.1 \%$ total ash, $1.2 \%$ crude fibre, $2.2 \mathrm{mg} / 100 \mathrm{~g} \mathrm{Fe}$, $10.6 \%$ carbohydrate, $80 \mathrm{mg} / 100 \mathrm{~g} \mathrm{Ca}$, and $53 \mathrm{mg} /$

*Author for correspondence; E-mail: ishfak90@gmail.com
$100 \mathrm{~g} \mathrm{P}$ (Bao and Chang, 1994). It is also a rich source of many vitamins like A, C, $\beta$-carotene, B1, B2 and B3 and minerals like calcium, potassium, phosphorus, sodium and iron (Krinsky and Johmson, 2005). The red colour of carrot is due to lycopene which it contains. Dietary fibres are helpful in prevention of heart diseases (Anderson et al., 1994) and carrots are good source of dietary fibres, carotenoids and phenols compounds (Bao and Chang, 1994), that is why it helps in prevention of diabetes, cardiovascular disease and stroke (Scalbert and Williams, 2000). Deficiency of vitamin A causes skin dryness, broken hairs and nails, and can cause night blindness (Shakeel et al., 2013). Carrots are used raw as well as cooked in the preparation of pickles and preserves various products like curries, pies, jam, beverages, wine and soups (Lingappa and Naik, 1997). Carrots are utilized in many vegetable dishes also (Amjad et al., 2005). Microorganisms and enzymes are inactivated by pasteurization to increase shelf life of the vegetable juices, which usually produced undesirable changes (Luciano et al., 2009). The vitamin A content in carrot is decreased along with increasing temperature and heating time (Chen et al., 1995). 
Apple comes under the umbrella of Rosaceae family and subfamily Pomoideae. It is an important fruit originated in south/western Asia, its production in Pakistan is bound to Punjab, Baluchistan and northern hilly areas of Khyber Pakhtunkhwa (Shah et al., 2002). Its sweet taste, shiny appearance and crispy flesh attract the consumers towards itself (Ali et al., 2004). Production wise Pakistan ranked on $10^{\text {th }}$ position in apple production throughout the world (GOP, 2011). Apple contains moisture $(84.7 \%)$, fibre $(0.8 \%)$, carbohydrates $(13.9 \%)$, ash $(0.3 \%)$, lipid $(0.3 \%)$, protein $(0.4 \%)$ and vitamin C (8 mg) (Hussain, 2001). Compared with other fruits and vegetables, apples have little amount of vitamin C (Boyer and Ruilin, 2004) and malic acid is the major organic acid (Campeanu et al., 2009). Like other fruits and vegetables, apple prevent colon cancer and also play a vital role in weight loss and many heart diseases. It contains calcium, iron, phosphorus and also rich in energy (Cecilia and Maia, 2002). Apple is mostly consumed in fresh form and cannot be stored for a longer time. Fresh apple can not be preserved for a long period of time. It is processed to get ready juices, jams, jelly, canned apple slices and dehydrated apple slices, etc. which is available all the time in the market. Due to lack of processing facilities, the losses are up to $50 \%$ yearly (Ilyas et al., 2007).

Various ingredients i.e., sugar, pectin, citric acid etc. play key role in preservation and acceptability of the product (Clarke, 1997). Sugar is a good source of flavour and hence provides good taste to product (Ayub et al., 2005). In jam and jellies sugar stop growth of microorganisms and prevent spoilage. Sugar holds water due to which shelf life of the products is increased (Clarke, 1997). They provide fermentation to the bread, bulk to ice cream and body to carbonated beverages (Ayub et al., 2005). Pectin being a gelling agent is responsible for gel formation in preparing jam (Fu and Rao, 2001). Stabilizing, thickening and textural characteristics are improved by pectin in different foods like jam, jelly, bakery products, confectionery and beverages. Peel of citrus contains high amount of pectin (Wang et al., 2002). Citric acid is essential during preparing jam as it inverts non-reducing sugars. For the replacement of citric acid, lime and lemon juice can be used in the jam preparation, because lemon and lime juices have greater amount of citric acid (Desrosier and Desrosier, 1978).

Jam is a semi-solid food product, obtained upon cooking of fruits or vegetables pulp with sugar, citric acid and pectin. Jam can be defined as an intermediate moisture food prepared by cooking sugar with fruit pulp, pectin, acid and other ingredients to a reasonable consistency. Jam should contain $65 \%$ or more TSS and at least $45 \%$ pulp (Shah et al., 2015). Jams generally have two types, the one which is developed from pulp of single fruit while the second type is prepared by blending two or more fruits pulp (Manay et al., 2005). The production of carrot and apple fruit is very much promising in Pakistan especially in Khyber Pakhtunkhwa because these fruits fetch more income to farmer. To promote this, the present research work was conducted to prepare a value added product from carrot and apple fruit and to study the influence of blends of carrot and apple in jam during storage. In this way, lots of raw fruits can be converted to a health beneficial product that can be available in the market throughout the year.

\section{Materials and Methods}

This research was conducted at laboratory of Food Science and Technology Section, Agriculture Research Institute, Tarnab, Peshawar. For the research work, carrots and apples were purchased from local market near Tarnab.

Sample preparation. Carrots were first washed with tap water to remove dust and dirt particles. Then trimmed to remove the lower hairy and bruised portion. The carrot fruit was cooked in $1 / 3$ of water in order to soften it to pass through pulper machine to extract the pulp. The treatments were formulated according to the proposed plan of study with different concentrations of carrot and apple pulp, $0.5 \%$ citric acid and $0.2 \%$ pectin. Carrot and apple pulp was combined in 6 different proportions by method as recommended by Shah et al. (2015). All batches were cooked to a reasonable consistency for the jam preparation.

Proposed plan of the study. Carrot and apple jam was prepared with the following different ratios.

$$
\begin{aligned}
& \mathrm{CA}_{0} \text { : Carrot pulp (100\%) + Apple pulp (0\%) } \\
& \mathrm{CA}_{1} \text { : Carrot pulp (90\%) + Apple pulp (10\%) } \\
& \mathrm{CA}_{2} \text { : Carrot pulp (80\%) + Apple pulp (20\%) } \\
& \mathrm{CA}_{3} \text { : Carrot pulp (70\%) + Apple pulp (30\%) } \\
& \mathrm{CA}_{4} \text { : Carrot pulp (60\%) + Apple pulp (40\%) } \\
& \mathrm{CA}_{5} \text { : Carrot pulp (50\%) + Apple pulp (50\%) }
\end{aligned}
$$

Packaging and storage of carrot apple jam. Carrot and apple jam was packed in sterilized $550 \mathrm{~g}$ glass jar. Samples were analysed for physicochemical and sensory characteristics. The samples were examined at fifteen days intervals and were kept for three months. 
Physicochemical analysis. Samples were examined for physicochemical properties i.e., total soluble solids (TSS), $\mathrm{pH}$, acidity, reducing sugar, non-reducing sugar and ascorbic acid by using the standard method of AOAC (2012).

Sensory evaluation. Carrot apple jam samples were evaluated for sensory characteristics such as colour, taste, texture and overall acceptability. Samples were examined by 10 judges by using 9 hedonic scale as described by Larmond (1977).

Statistical analysis. The data was analysed by using two factorial CRD and means were separated by applying LSD test at $0.05 \%$ significant level as described by Steel and Torrie (1997).

\section{Results and Discussion}

Total soluble solids ( $\left({ }^{0} \mathrm{brix}\right)$. The effect of storage intervals and different treatments on total soluble solid contents of jam samples are shown in Table 1. The statistical analysis revealed that TSS of apple and carrot jam increased significantly $(\mathrm{P}<0.05)$ in various treatments during storage period. The TSS of the samples in the initial day were 67.6, 67.4, 67.3, 67.5, 67.6 and 67 from $\mathrm{CA}_{0}$ to $\mathrm{CA}_{5}$, which gradually increased to 71.7 , $70.8,70.3,70.3,70.2$ and 69.6 in respective way, during 90 days of storage. The maximum percent increase was found in $\mathrm{CA}_{0}$ (5.72), while the lowest percent increase was recorded at $\mathrm{CA}_{5}$ (3.02). The increasing trend of total soluble solids might be due to the degradation of polysaccharide in the presence of acid. Also most of the solid become soluble slowly due to which the TSS increased gradually. The present findings are in accordance with the observed value of Shakir et al. (2007), who found an increasing tendency (68.5-71.2 ${ }^{\circ}$ brix) during 90 days storage period of pear apple jam. Similarly, Khan et al. (2012) also observed an increase in TSS from 66.5 to $68.8^{\circ}$ brix in fruit jam. Ehsan et al. (2003) and Ehsan et al. (2002) also found an increase in TSS (70 to $70.8^{\circ}$ brix) in watermelon and lemon jam.

pH. The statistically analysed value showed that $\mathrm{pH}$ of the jam samples is significantly $(\mathrm{P}<0.05)$ influenced by the treatments and storage intervals (Table 2). The $\mathrm{pH}$ of carrot/apple jam decreased step by step with the passage of time during storage. The fresh values of the samples were 3.7, 3.65, 3.63, 3.58, 3.59 and 3.61, from $\mathrm{CA}_{0}$ to $\mathrm{CA}_{5}$ which gradually decreased to $3.48,3.45$, $3.44,3.41,3.43$ and 3.47 , respectively during 90 days period. The highest percent decrease (5.95) was noted at $\mathrm{CA}_{0}$, however $\mathrm{CA}_{5}$ (3.88) showed the lowest percent decrease in $\mathrm{pH}$ of the jam samples. Decreasing trend in $\mathrm{pH}$ might be due to hydrolysis of pectic bodies and formation of acidic compound during degradation of sugar contents. The present findings are supported by the work of Ehsan et al. (2002), who investigated that the $\mathrm{pH}$ of watermelon lemon jam samples showed decreasing trends during time intervals. $\mathrm{pH}$ of the fruit sample is very important, as it helps in the formation of optimum gel in the preparation of jam. In contrast, the $\mathrm{pH}$ value of apple and apricot jam studied by Hussain and Shakir (2010) were found to be somewhat higher than the present findings. The rise in acidity of jam samples during storage period resulted from the formation of acidic compound resulted in the decrease of $\mathrm{pH}$. Similarly, previous literature supported the present findings, as they also studied fall in the $\mathrm{pH}$ values of fruit jam during storage (Shakir et al., 2007).

Table 1. Influence of treatments and storage intervals on total soluble solids of carrot pulp fortified apple pulp blended jam

\begin{tabular}{|c|c|c|c|c|c|c|c|c|c|}
\hline \multirow[t]{2}{*}{ Treatments } & \multicolumn{7}{|c|}{ Storage intervals (days) } & \multirow[t]{2}{*}{$\%$ Increase } & \multirow[t]{2}{*}{ Means } \\
\hline & $\overline{0}$ & 15 & 30 & 45 & 60 & 75 & 90 & & \\
\hline $\mathrm{CA}_{0}$ & 67.6 & 68 & 68.4 & 68.9 & 70.5 & 71.1 & 71.7 & 5.72 & $69.46 \mathrm{a}$ \\
\hline $\mathrm{CA}_{1}$ & 67.4 & 67.7 & 68.1 & 68.7 & 69.3 & 70 & 70.8 & 4.8 & $68.86 \mathrm{~b}$ \\
\hline $\mathrm{CA}_{2}$ & 67.3 & 67.6 & 68 & 68.5 & 69.1 & 69.7 & 70.3 & 4.27 & $68.64 b c$ \\
\hline $\mathrm{CA}_{3}$ & 67.5 & 67.8 & 68.1 & 68.5 & 69.1 & 69.7 & 70.3 & 3.98 & $68.71 b c$ \\
\hline $\mathrm{CA}_{4}$ & 67.6 & 67.9 & 68.2 & 68.6 & 69.1 & 69.6 & 70.2 & 3.7 & $68.74 b c$ \\
\hline $\mathrm{CA}_{5}$ & 67.5 & 67.7 & 68 & 68.3 & 68.7 & 69.1 & 69.6 & 3.02 & $68.41 \mathrm{c}$ \\
\hline Means & $67.45 f$ & $67.75 \mathrm{ef}$ & $68.10 \mathrm{e}$ & $68.58 \mathrm{~d}$ & $69.15 c$ & $69.75 b$ & $70.40 \mathrm{a}$ & & \\
\hline
\end{tabular}

Mean followed by different letters are significantly different from each other. 
Table 2. Influence of treatments and storage intervals on $\mathrm{pH}$ of carrot pulp fortified apple pulp blended jam

\begin{tabular}{|c|c|c|c|c|c|c|c|c|c|}
\hline \multirow[t]{2}{*}{ Treatments } & \multicolumn{7}{|c|}{ Storage intervals (days) } & \multirow[t]{2}{*}{$\%$ Increase } & \multirow[t]{2}{*}{ Means } \\
\hline & 0 & 15 & 30 & 45 & 60 & 75 & 90 & & \\
\hline $\mathrm{CA}_{0}$ & 3.7 & 3.67 & 3.64 & 3.6 & 3.56 & 3.52 & 3.48 & 5.95 & $3.60 \mathrm{a}$ \\
\hline $\mathrm{CA}_{1}$ & 3.65 & 3.62 & 3.59 & 3.56 & 3.53 & 3.49 & 3.45 & 5.48 & $3.56 b$ \\
\hline $\mathrm{CA}_{2}$ & 3.63 & 3.61 & 3.58 & 3.55 & 3.52 & 3.48 & 3.44 & 5.23 & $3.54 \mathrm{c}$ \\
\hline $\mathrm{CA}_{3}$ & 3.58 & 3.56 & 3.53 & 3.5 & 3.47 & 3.44 & 3.41 & 4.75 & $3.50 \mathrm{e}$ \\
\hline $\mathrm{CA}_{4}$ & 3.59 & 3.57 & 3.55 & 3.52 & 3.49 & 3.46 & 3.43 & 4.46 & $3.52 \mathrm{~d}$ \\
\hline $\mathrm{CA}_{5}$ & 3.61 & 3.6 & 3.58 & 3.56 & 3.53 & 3.5 & 3.47 & 3.88 & $3.55 \mathrm{bc}$ \\
\hline Means & $3.63 \mathrm{a}$ & $3.61 b$ & $3.58 \mathrm{c}$ & $3.55 \mathrm{~d}$ & $3.51 \mathrm{e}$ & $3.48 \mathrm{f}$ & $3.44 \mathrm{~g}$ & & \\
\hline
\end{tabular}

Mean followed by different letters are significantly different from each other.

Titratable acidity. The effect of treatments and storage interval on the percent acidity of carrot and apple blended jam samples are shown in Table 3 . The percent acidity of various jam samples showed significant $(\mathrm{P}<0.05)$ difference during storage period. The percent acidity of the jam samples were $0.65,0.63,0.65,0.61$, 0.64 and $0.64\left(\mathrm{CA}_{0}\right.$ to $\left.\mathrm{CA}_{5}\right)$ at first day, while showed an increasing trend of $0.87,0.81,0.82,0.75,0.78$ and 0.76 correspondingly during three months storage interval. Mean acidity value at first day of storage was 0.64 , which increased to 0.80 . The highest mean value of 0.75 was recorded at $\mathrm{CA}_{0}$, while the lowest value of 0.67 was recorded at $\mathrm{CA}_{3}$. $\mathrm{CA}_{0}$ showed the maximum percent increase in acidity (25.29), while $\mathrm{CA}_{5}$ showed the minimum increase in percent acidity followed by $\mathrm{CA}_{4}$ (17.95). The increase in acidity of the apple and olive blended jam might be due to the breakdown of pectic bodies to pectenic acid. The reason for increasing trend of acidity was due to the formation of different organic acids during carbohydrates degradation and hydrolysis at storage. The present findings are supported by the findings of Anjum et al. (2000), who found an increase in percent acidity $(0.65-0.70 \%)$ of apricot jam during storage period. Similarly, the increase in acidity from 0.68 to $0.86 \%$ was observed in strawberry jam by Khan et al. (2012). Ehsan et al. (2002) also found an increase in percent acidity of the jam throughout storage interval. Similarly, Shakir et al. (2007) also found raise in acidity from 0.60 to $0.78 \%$ during storage. The increase in acidity of fruit jam also resulted due to sugar breakdown and increase in the total soluble solid contents of the samples (Sogi and Singh, 2001).

Reducing sugar. The influence of storage interval and treatments on the reducing sugar of jam samples are shown in Table 4. The values of reducing sugar increased significantly $(\mathrm{P}<0.05)$ in carrot and apple blended jam on both treatments and storage. The observed value of reducing sugars of the jam samples from $\mathrm{CA}_{0}$ to $\mathrm{CA}_{5}$ at initial day were $16.74,16.71,16.54,16.56,16.65$ and 16.58. The reducing sugar of the various samples increased gradually $(29.92,28.86,27.42,26.65,26.07$

Table 3. Influence of treatments and storage intervals on titratable acidity (\%) of carrot pulp fortified apple pulp blended jam

\begin{tabular}{|c|c|c|c|c|c|c|c|c|c|}
\hline \multirow[t]{2}{*}{ Treatments } & \multicolumn{7}{|c|}{ Storage intervals (days) } & \multirow[t]{2}{*}{$\%$ Increase } & \multirow[t]{2}{*}{ Means } \\
\hline & 0 & 15 & 30 & 45 & 60 & 75 & 90 & & \\
\hline $\mathrm{CA}_{0}$ & 0.65 & 0.68 & 0.71 & 0.74 & 0.78 & 0.82 & 0.87 & 25.29 & $0.75 \mathrm{a}$ \\
\hline $\mathrm{CA}_{1}$ & 0.63 & 0.65 & 0.67 & 0.7 & 0.73 & 0.77 & 0.81 & 22.22 & $0.71 \mathrm{c}$ \\
\hline $\mathrm{CA}_{2}$ & 0.65 & 0.67 & 0.69 & 0.72 & 0.75 & 0.78 & 0.82 & 20.73 & $0.73 b$ \\
\hline $\mathrm{CA}_{3}$ & 0.61 & 0.63 & 0.65 & 0.67 & 0.69 & 0.72 & 0.75 & 18.67 & $0.67 \mathrm{e}$ \\
\hline $\mathrm{CA}_{4}$ & 0.64 & 0.66 & 0.68 & 0.7 & 0.72 & 0.75 & 0.78 & 17.95 & $0.70 \mathrm{~cd}$ \\
\hline $\mathrm{CA}_{5}$ & 0.64 & 0.65 & 0.67 & 0.69 & 0.71 & 0.73 & 0.76 & 15.79 & $0.69 \mathrm{~d}$ \\
\hline Means & $0.64 \mathrm{~g}$ & $0.66 \mathrm{f}$ & $0.68 \mathrm{e}$ & $0.71 \mathrm{~d}$ & $0.73 \mathrm{c}$ & $0.77 \mathrm{~b}$ & $0.80 \mathrm{a}$ & & \\
\hline
\end{tabular}

Mean followed by different letters are significantly different from each other. 
and 25.28) during storage period. The maximum percent increase (44.05) was found in $\mathrm{CA}_{0}$, while the lowest percent increase of 34.41 was found in $\mathrm{CA}_{5}$. The reason for increasing the reducing sugar might be due to the presence of invertase enzymes but invertase enzymes works properly at $4.6 \mathrm{pH}$ and $50{ }^{\circ} \mathrm{C}$ temperature and since the temperature was ambient in this condition, thus making it inadequate for activity of invertase enzyme. The increase in reducing sugar might be due to the inversion of non reducing sugar to reducing sugar during storage. The inversion of non reducing sugar was due to the presence of acid along with high temperature that speed up the inversion process. The analysis of reducing sugar of strawberry jam during storage interval showed an increasing trend (Riaz et al., 1999), hence justifying the present results. Similarly, the reducing sugar of apricot jam also increased significantly during storage period (Anjum et al., 2000). Ehsan et al. (2003) found that the reducing sugar of grape and apple marmalade increased from 16.55 to 31.36 during keeping period. The raise in the reducing sugar is caused by the conversion of sucrose to glucose and fructose, due to temperature and acidic condition (Singh et al., 1999).

Non-reducing sugar. The influence of treatments and storage interval on non-reducing sugar content of carrot and apple blended jam are shown in Table 5. It was found from statistics analysis that the value of nonreducing sugar of the jam reduced considerably $(\mathrm{P}<0.05)$ on both storage and treatments. The observed value from $\mathrm{CA}_{0}$ to $\mathrm{CA}_{5}$ of non-reducing sugar at initial day was 43.40, 45.10, 43.20, 47.00, 46.50 and 46.36, respectively. While, during storage period the nonreducing sugar content decreased gradually to 23.56 , $26.80,26.26,30.08,31.77$ and 33.54 correspondingly. The sample $\mathrm{CA}_{0}$ showed the maximum \% decrease (45.71) in case of non-reducing sugar, which is followed by the sample $\mathrm{CA}_{1}$ (40.58). The present results are in close contract with the findings of Riaz et al. (1999), who found a decline in the non-reducing sugars (44.6432.35 ) of the strawberry jam during storage period. A decline in non-reducing sugar during the storage

Table 4. Influence of treatments and storage intervals on reducing sugar (\%) of carrot pulp fortified apple pulp blended jam

\begin{tabular}{|c|c|c|c|c|c|c|c|c|c|}
\hline \multirow[t]{2}{*}{ Treatments } & \multicolumn{7}{|c|}{ Storage intervals (days) } & \multirow[t]{2}{*}{$\%$ Increase } & \multirow[t]{2}{*}{ Means } \\
\hline & $\overline{0}$ & 15 & 30 & 45 & 60 & 75 & 90 & & \\
\hline $\mathrm{CA}_{0}$ & 16.74 & 18.08 & 19.67 & 21.95 & 24.44 & 27.05 & 29.92 & 44.05 & $22.55 \mathrm{a}$ \\
\hline $\mathrm{CA}_{1}$ & 16.71 & 18.43 & 20.37 & 22.15 & 24.37 & 26.62 & 28.86 & 42.10 & $22.50 \mathrm{a}$ \\
\hline $\mathrm{CA}_{2}$ & 16.54 & 17.46 & 18.83 & 20.34 & 21.95 & 24.36 & 27.42 & 39.68 & $20.99 b c$ \\
\hline $\mathrm{CA}_{3}$ & 16.56 & 17.69 & 19.12 & 20.83 & 22.55 & 24.48 & 26.65 & 37.86 & $21.13 b$ \\
\hline $\mathrm{CA}_{4}$ & 16.65 & 17.72 & 19.04 & 20.55 & 22.13 & 23.82 & 26.07 & 36.13 & $20.85 b c$ \\
\hline $\mathrm{CA} 5$ & 16.58 & 17.36 & 18.41 & 19.78 & 21.26 & 23.17 & 25.28 & 34.41 & $20.26 c$ \\
\hline Means & $16.64 \mathrm{~g}$ & $17.88 \mathrm{f}$ & $19.41 \mathrm{e}$ & $21.16 \mathrm{~d}$ & $23.09 \mathrm{c}$ & $25.27 b$ & $27.78 \mathrm{a}$ & & \\
\hline
\end{tabular}

Mean followed by different letters are significantly different from each other.

Table 5. Influence of treatments and storage intervals on non-reducing sugar (\%) of carrot pulp fortified apple pulp blended jam

\begin{tabular}{|c|c|c|c|c|c|c|c|c|c|}
\hline \multirow[t]{2}{*}{ Treatments } & \multicolumn{7}{|c|}{ Storage intervals (days) } & \multirow[t]{2}{*}{$\%$ Increase } & \multirow[t]{2}{*}{ Means } \\
\hline & 0 & 15 & 30 & 45 & 60 & 75 & 90 & & \\
\hline $\mathrm{CA}_{0}$ & 43.4 & 41.28 & 38.2 & 34.95 & 31.28 & 27.11 & 23.56 & 45.71 & $34.25 \mathrm{~d}$ \\
\hline $\mathrm{CA}_{1}$ & 45.1 & 42.45 & 39.67 & 36.56 & 33.12 & 29.66 & 26.8 & 40.58 & $36.19 \mathrm{c}$ \\
\hline $\mathrm{CA}_{2}$ & 43.2 & 41.64 & 39.05 & 36.17 & 32.92 & 29.65 & 26.26 & 39.21 & $35.56 \mathrm{c}$ \\
\hline $\mathrm{CA}_{3}$ & 47 & 44.75 & 42.07 & 39.21 & 36.11 & 33.23 & 30.08 & 36.00 & $38.92 b$ \\
\hline $\mathrm{CA}_{4}$ & 46.5 & 44.78 & 42.38 & 40.05 & 37.83 & 34.55 & 31.77 & 31.68 & $39.69 \mathrm{ab}$ \\
\hline $\mathrm{CA}_{5}$ & 46.36 & 44.77 & 42.95 & 40.73 & 38.36 & 35.85 & 33.54 & 27.65 & $40.37 \mathrm{a}$ \\
\hline Means & $45.04 \mathrm{a}$ & $42.98 b$ & $40.27 \mathrm{c}$ & $37.39 \mathrm{~d}$ & $34.25 \mathrm{e}$ & $30.84 f$ & $27.69 \mathrm{~g}$ & & \\
\hline
\end{tabular}

Mean followed by different letters are significantly different from each other. 
intervals is obtained in grape and apple marmalade and banana and mushroom blended jam throughout the storage period (Khan et al., 2017; Ehsan et al., 2003). Similarly, Shakir et al. (2007) also observed a decline in non-reducing sugar in pear apple jam. The increase in reducing sugar is caused by conversion of sucrose to glucose and fructose, due to temperature and acidic condition (Shah et al., 2015; Singh et al., 1999).

Ascorbic acid. The ascorbic acid content of carrot and apple jam was significantly $(\mathrm{P}<0.05)$ affected during storage period (Table 6). The initial day reading for ascorbic acid content from $\mathrm{CA}_{0}$ to $\mathrm{CA}_{5}$ were 4.52, 5.78, $7.82,8.86,9.22$ and 9.65, respectively, which substantially decreased to $2.8,4.55,5.40,6.35,6.77$ and 7.25, respectively during 3 months of storage period. Mean ascorbic acid value of 7.81 was observed at initial day, which decreased to 5.52 during 90 days of storage period. The highest mean value of 8.61 was noted by the sample $\mathrm{CA}_{5}$, while lowest mean value of 3.83 was noted at $\mathrm{CA}_{0}$. Maximum percent decrease of 38.05 was observed at $\mathrm{CA}_{0}$ followed by the sample $\mathrm{CA}_{1}$ (32.89), while the minimum percent decrease was found at $\mathrm{CA}_{5}$ (24.87) followed by $\mathrm{CA}_{4}$ (26.57). The ascorbic acid content of strawberry jam significantly decreased from $18 \mathrm{mg} / 100 \mathrm{~g}$ to $13 \mathrm{mg} / 100 \mathrm{~g}$ throughout the storage interval (Riaz et al., 1999). Similar trend of decline in ascorbic acid content of fruit jam was observed by Jawaheer et al. (2003). The loss of ascorbic acid content is due to the effect of light in the storage environment of the product. Ascorbic acid is the most important nutrient that represents the quality characteristics of the product, which is substantially affected due to oxidation during processing and storage (Veltman et al., 2000).

Colour. Storage intervals and treatments significantly $(\mathrm{P}<0.05)$ affect the colour of carrot and apple mixed jam during storage interval (Table 7). The sensory panelist scores for color of carrot and apple jam decreased significantly $(\mathrm{P}<0.05)$ during the storage time. At initial day, the sensory score for colour of the samples from $\mathrm{CA}_{0}$ to $\mathrm{CA}_{5}$ were 6.7, 7.0, 7.1, 7.7, 7.7 and 7.9, which decreased substantially to $1.5,3.6,4.3,5.2,5.6$ and 5.9 , respectively throughout storage intervals. The highest

Table 6. Influence of treatments and storage intervals on ascorbic acid (mg/100 g) of carrot pulp fortified apple pulp blended jam

\begin{tabular}{|c|c|c|c|c|c|c|c|c|c|}
\hline \multirow[t]{2}{*}{ Treatments } & \multicolumn{7}{|c|}{ Storage intervals (days) } & \multirow[t]{2}{*}{$\%$ Increase } & \multirow[t]{2}{*}{ Means } \\
\hline & $\overline{0}$ & 15 & 30 & 45 & 60 & 75 & 90 & & \\
\hline $\mathrm{CA}_{0}$ & 4. 52 & 4. 4 & 4. 22 & 3.97 & 3.65 & 3.24 & 2.8 & 38.05 & 3. $83 \mathrm{f}$ \\
\hline $\mathrm{CA}_{1}$ & 6.78 & 6.52 & 6.23 & 5.92 & 5.48 & 5.09 & 4.55 & 32.89 & $5.80 \mathrm{e}$ \\
\hline $\mathrm{CA}_{2}$ & 7.82 & 7. 43 & 7.15 & 6.76 & 6.44 & 5.95 & 5.4 & 30.95 & 6. $71 \mathrm{~d}$ \\
\hline $\mathrm{CA}_{3}$ & 8.86 & 8.62 & 8.28 & 7.83 & 7.37 & 6.83 & 6.35 & 28.33 & $7.73 \mathrm{c}$ \\
\hline $\mathrm{CA}_{4}$ & 9.22 & 9 & 8.66 & 8.29 & 7.85 & 7.31 & 6.77 & 26.57 & 8. $16 \mathrm{~b}$ \\
\hline $\mathrm{CA}_{5}$ & 9.65 & 9.43 & 9.14 & 8.81 & 8.28 & 7.74 & 7.25 & 24.87 & 8. $61 \mathrm{a}$ \\
\hline Means & 7. $81 \mathrm{a}$ & 7. $57 \mathrm{~b}$ & 7. $28 \mathrm{c}$ & $6.93 \mathrm{~d}$ & $6.51 \mathrm{e}$ & 6. $03 \mathrm{f}$ & $5.52 \mathrm{~g}$ & & \\
\hline
\end{tabular}

Mean followed by different letters are significantly different from each other.

Table 7. Influence of treatments and storage intervals on colour score of carrot pulp fortified apple pulp blended jam

\begin{tabular}{|c|c|c|c|c|c|c|c|c|c|}
\hline \multirow[t]{2}{*}{ Treatments } & \multicolumn{7}{|c|}{ Storage intervals (days) } & \multirow[t]{2}{*}{$\%$ Increase } & \multirow[t]{2}{*}{ Means } \\
\hline & 0 & 15 & 30 & 45 & 60 & 75 & 90 & & \\
\hline $\mathrm{CA}_{0}$ & 6.7 & 6.2 & 5.5 & 4.6 & 3.5 & 2.4 & 1.5 & 77.61 & $4.34 \mathrm{c}$ \\
\hline $\mathrm{CA}_{1}$ & 7 & 6.6 & 6.2 & 5.8 & 5.1 & 4.4 & 3.6 & 48.57 & $5.53 b$ \\
\hline $\mathrm{CA}_{2}$ & 7.1 & 6.8 & 6.5 & 6.1 & 5.6 & 5 & 4.3 & 39.44 & $5.91 b$ \\
\hline $\mathrm{CA}_{3}$ & 7.7 & 7.4 & 7.1 & 6.7 & 6.3 & 5.8 & 5.2 & 32.47 & $6.60 \mathrm{a}$ \\
\hline $\mathrm{CA}_{4}$ & 7.7 & 7.4 & 7.1 & 6.8 & 6.5 & 6.1 & 5.6 & 27.27 & $6.74 a$ \\
\hline $\mathrm{CA}_{5}$ & 7.8 & 7.6 & 7.4 & 7.1 & 6.8 & 6.4 & 5.9 & 24.36 & $7.00 \mathrm{a}$ \\
\hline Means & $7.33 \mathrm{a}$ & $7.00 \mathrm{ab}$ & $6.63 \mathrm{bc}$ & $6.18 \mathrm{~cd}$ & $5.63 \mathrm{~d}$ & $5.02 \mathrm{e}$ & $4.35 f$ & & \\
\hline
\end{tabular}

Mean followed by different letters are significantly different from each other. 
$\%$ decrease of 77.61 was observed at $\mathrm{CA}_{0}$ followed by $\mathrm{CA}_{1}$ (48.57), while the minimum $\%$ decrease was noted at $\mathrm{CA}_{5}$ (24.36) followed by $\mathrm{CA}_{4}$ (27.27). Changes in colour might be attributed to Maillard reaction, enzymatic browning ascorbic acid degradation and polymerization of colour pigments (carotenoids and anthocyanin's) with other phenolic compound. Similarly, Khan et al. (2012) investigated that colour mean was decreased from 9.00 to 7.00 in strawberry jam. The colour of food product is the most important parameters regarding consumer's opinion. During storage, the colour of the product is significantly degraded. Decline in colour score may be due to degradation of ascorbic acid and enzymatic browning (Gimenez et al., 2001).

Taste. The effect of treatments and storage on taste of mixed jam samples is depicted in Table 8. The statistical data representing the panelist scores for taste of jam reduced considerably $(\mathrm{P}<0.05)$ during keeping time. The sensory score for taste of carrot and apple blended jam at initial day were $6.1,6.8,7.8,8.20,8.10$ and 8.20 $\left(\mathrm{CA}_{0}\right.$ to $\left.\mathrm{CA}_{5}\right)$, which gradually obtained a lower score from the sensory panels $(1.3,3.9,4.7,5.2,5.5$ and 6.2) during the period of storage. The maximum decrease of $78.69 \%$ was observed by $\mathrm{CA}_{0}$, while minimum decrease of 24.39 was observed by $\mathrm{CA}_{5}$. Organic acid and sugar ratio primarily creates a sense of taste which is perceived by specialized taste buds on the tongue. Decrease in taste score might be due to the fluctuation in acids, $\mathrm{pH}$ and sugar/acid ratio. The present results are in accordance with the work of Muhammad et al. (2009), who investigated a decrease in taste scores of apple jam from 8.60 to 5.90 throughout 90 days. However, Ehsan et al. (2002) recorded a decline in the taste scores of watermelon and lemon jam during five month of storage period. Decline in taste score might be due to fluctuation in acids or decrease in $\mathrm{pH}$ (Rathore et al., 2007).

Texture. The statistical analysis of the samples showed that texture of carrot and apple jam differed significantly $(\mathrm{P}<0.05)$ both by treatments and storage intervals (Table 9). The mean sensory scores for texture of the jam decreased significantly $(\mathrm{P}<0.05)$ on both treatments and storage intervals. The panelist scores for texture of

Table 8. Influence of treatments and storage intervals on taste score of carrot pulp fortified apple pulp blended jam

\begin{tabular}{|c|c|c|c|c|c|c|c|c|c|}
\hline \multirow[t]{2}{*}{ Treatments } & \multicolumn{7}{|c|}{ Storage intervals (days) } & \multirow[t]{2}{*}{$\%$ Increase } & \multirow[t]{2}{*}{ Means } \\
\hline & 0 & 15 & 30 & 45 & 60 & 75 & 90 & & \\
\hline $\mathrm{CA}_{0}$ & 6.1 & 5.6 & 5 & 4.4 & 3.4 & 2.3 & 1.3 & 78.69 & $4.01 \mathrm{e}$ \\
\hline $\mathrm{CA}_{1}$ & 6.8 & 6.5 & 6.1 & 5.7 & 5.2 & 4.6 & 3.9 & 42.65 & $5.54 d$ \\
\hline $\mathrm{CA}_{2}$ & 7.8 & 7.5 & 7.1 & 6.7 & 6.2 & 5.6 & 4.7 & 39.74 & $6.51 \mathrm{c}$ \\
\hline $\mathrm{CA}_{3}$ & 8.2 & 7.9 & 7.5 & 7 & 6.5 & 5.9 & 5.2 & 36.59 & $6.89 \mathrm{bc}$ \\
\hline $\mathrm{CA}_{4}$ & 8.1 & 7.8 & 7.5 & 7.1 & 6.6 & 6.1 & 5.5 & 32.10 & $6.96 \mathrm{~b}$ \\
\hline $\mathrm{CA}_{5}$ & 8.2 & 8 & 7.8 & 7.5 & 7.2 & 6.7 & 6.2 & 24.39 & $7.37 \mathrm{a}$ \\
\hline Means & $7.40 \mathrm{a}$ & $7.06 \mathrm{ab}$ & $6.64 b$ & $6.18 \mathrm{c}$ & $5.58 \mathrm{~d}$ & $4.90 \mathrm{e}$ & $4.12 \mathrm{f}$ & & \\
\hline
\end{tabular}

Mean followed by different letters are significantly different from each other.

Table 9. Influence of treatments and storage intervals on texture score of carrot pulp fortified apple pulp blended jam

\begin{tabular}{|c|c|c|c|c|c|c|c|c|c|}
\hline \multirow[t]{2}{*}{ Treatments } & \multicolumn{7}{|c|}{ Storage intervals (days) } & \multirow[t]{2}{*}{$\%$ Increase } & \multirow[t]{2}{*}{ Means } \\
\hline & 0 & 15 & 30 & 45 & 60 & 75 & 90 & & \\
\hline $\mathrm{CA}_{0}$ & 6.9 & 6.5 & 6 & 5.2 & 4.3 & 3.2 & 1.8 & 73.91 & $4.84 \mathrm{e}$ \\
\hline $\mathrm{CA}_{1}$ & 7 & 6.7 & 6.3 & 5.8 & 5.3 & 4.7 & 4 & 42.86 & $5.69 \mathrm{~d}$ \\
\hline $\mathrm{CA}_{2}$ & 7.1 & 6.8 & 6.5 & 6.1 & 5.6 & 5 & 4.3 & 39.44 & $5.91 \mathrm{~cd}$ \\
\hline $\mathrm{CA}_{3}$ & 7.5 & 7.2 & 6.9 & 6.5 & 6 & 5.5 & 4.9 & 34.67 & $6.36 \mathrm{bc}$ \\
\hline $\mathrm{CA}_{4}$ & 7.6 & 7.3 & 7 & 6.7 & 6.3 & 5.8 & 5.3 & 30.26 & $6.57 \mathrm{ab}$ \\
\hline $\mathrm{CA}_{5}$ & 7.7 & 7.5 & 7.2 & 6.9 & 6.6 & 6.2 & 5.8 & 24.68 & $6.84 a$ \\
\hline Means & $7.22 \mathrm{a}$ & $6.90 \mathrm{ab}$ & $6.54 \mathrm{bc}$ & $6.06 \mathrm{c}$ & $5.50 \mathrm{~d}$ & $4.84 \mathrm{e}$ & $4.06 f$ & & \\
\hline
\end{tabular}

Mean followed by different letters are significantly different from each other. 
Table 10. Influence of treatments and storage intervals on overall acceptability score of carrot pulp fortified apple pulp blended jam

\begin{tabular}{|c|c|c|c|c|c|c|c|c|c|}
\hline \multirow[t]{2}{*}{ Treatments } & \multicolumn{7}{|c|}{ Storage intervals (days) } & \multirow[t]{2}{*}{$\%$ Increase } & \multirow[t]{2}{*}{ Means } \\
\hline & 0 & 15 & 30 & 45 & 60 & 75 & 90 & & \\
\hline $\mathrm{CA}_{0}$ & 6.8 & 6.3 & 5.8 & 5.1 & 4.3 & 3.1 & 1.6 & 76.47 & $4.71 d$ \\
\hline $\mathrm{CA}_{1}$ & 7 & 6.7 & 6.4 & 6 & 5.4 & 4.8 & 4 & 42.86 & $5.76 \mathrm{c}$ \\
\hline $\mathrm{CA}_{2}$ & 7.2 & 6.9 & 6.5 & 6.1 & 5.6 & 5 & 4.4 & 38.89 & $5.96 \mathrm{c}$ \\
\hline $\mathrm{CA}_{3}$ & 7.8 & 7.5 & 7.1 & 6.7 & 6.2 & 5.7 & 5.1 & 34.62 & $6.59 b$ \\
\hline $\mathrm{CA}_{4}$ & 8 & 7.7 & 7.4 & 7 & 6.6 & 6.1 & 5.6 & 30 & $6.91 \mathrm{ab}$ \\
\hline $\mathrm{CA}_{5}$ & 8 & 7.8 & 7.6 & 7.3 & 7 & 6.6 & 6.1 & 23.75 & $7.20 \mathrm{a}$ \\
\hline Means & $7.36 \mathrm{a}$ & $7.02 \mathrm{ab}$ & $6.64 b c$ & $6.18 \mathrm{c}$ & $5.62 \mathrm{~d}$ & $4.94 \mathrm{e}$ & $4.14 f$ & & \\
\hline
\end{tabular}

Mean followed by different letters are significantly different from each other.

carrot and apple jam from $\mathrm{CA}_{0}$ to $\mathrm{CA}_{5}$ at day one were 6.9, 7.0, 7.1, 7.5, 7.6 and 7.7. However, during storage interval, texture of the jam samples decreased gradually to $1.8,4.0,4.3,4.9,5.3$ and 5.8 in respective form. The maximum percent decrease in the texture of the mixed jam was recorded in $\mathrm{CA}_{0}$ (73.91), while minimum decrease of $24.68 \%$ was observed at $\mathrm{CA}_{5}$. The textural properties of the jam are usually attributed to pectic bodies composition. The pectic bodies in carrot fruit are very low as compared to apple fruit. The decrease in pectic substance with storage significantly affects the texture score of the carrot pulp fortified apple pulp blended jam. The present findings are in accordance with the observed values of Suutarinen et al. (2000), who observed a gradual decline in the texture properties of strawberry jam. The present value for texture are found to be slightly lower than the findings of Ehsan et al. (2003), who observed a decrease in the value of texture of grape and apple marmalade during storage. Similarly, Muhammad et al. (2009) analysed decrease in texture score from 9.00 to 6.70 in apple jam.

Overall acceptability. The effect of treatments and storage interval on overall acceptability of carrot and apple blended jam is presented in Table 10. The overall acceptability scores of the jam reduced considerably $(\mathrm{P}<0.05)$ on both treatments and storage. The overall acceptance score of carrot and apple jam at first day from $\mathrm{CA}_{0}$ to $\mathrm{CA}_{5}$ were 6.8, 7.0, 7.2, 7.8, 8.0 and 8.0, which fall gradually to $1.6,4.0,4.4,5.1,5.6$ and 6.1, respectively during the storage time. The highest percent decrease of 76.47 was recorded at $\mathrm{CA}_{0}$ followed by $\mathrm{CA}_{1}$ (42.86), while minimum percent decrease of 23.75 was recorded at $\mathrm{CA}_{5}$ followed by $\mathrm{CA}_{4}$ (30.00). The carrot pulp fortified apple pulp blended jam remains acceptable after 90 days of storage period. Sensory traits are non-generally interrelated and contribute independently towards the overall sensory perception. The overall acceptance of grape and apple marmalade decreased from 8.8 to 7.96 during the storage interval (Ehsan et al. 2003), thus supporting the present results. Khan et al. (2012) also examined similar results of decreasing trends (9.00 to 7.00$)$ in overall acceptability in fruit jam. Similarly, Ehsan et al. (2002) found decline in the overall acceptability of lemon and watermelon jam.

\section{Conclusion}

The prepared jam samples from various blends of carrot and apple pulp were evaluated for physicochemical and sensory characteristics for three months of storage period. It was found that storage has great effect on the quality and stability of carrot apple jam. Total soluble solids, percent acidity and reducing sugar were increased, while $\mathrm{pH}$ and non-reducing sugar were decreased significantly during storage period. The sensory analysis of the blended jam samples showed acceptable attributes in term of taste, colour, texture and overall acceptance, which significantly degrades during keeping period. Results also revealed that as the apple content increases, the textural property becomes improved and better. On the basis of the analysis, it was concluded that treatment $\mathrm{CA}_{5}$, followed by $\mathrm{CA}_{4}$ were of good qualities among the treatments.

\section{Acknowledgement}

Special thanks to Mr. Falak Naz Shah, Principal Research Officer, Food Technology Section, ARI Tarnab, Peshawar for assistance during this research. 


\section{References}

GOP, 2010-2011. Agriculture Statistics of Pakistan, pp. 92, Government of Pakistan, Statistics Division, Pakistan Bureau of Statistics, Islamabad, Pakistan.

Ali, A., Raza, M.H., Khan, M.A., Manzoor, H. 2004. Effect of different periods of ambient storage on chemical composition of apple fruit. International Journal of Agriculture and Biology, 6: 568-571.

Ali, M., Abedullah. 2002. Nutritional and economic benefits of enhanced vegetable production and consumption. Journal of Crop Production, 6: 145176.

Amjad, M., Naz, S., Ali, S. 2005. Growth and seed yield of carrot as influenced by different regimes of nitrogen and potassium. Journal of Research Science, 16: 73-78.

Anderson, J.W., Smith, B.M., Guftanson, N.J. 1994. Health benefits and practical aspects of high fiber diets. American Journal of Clinical Nutrition, 59: 1242-1247.

Anjum, F.M., Din, M.U., Ahmad, I., Pasha, A.R. 2000. Preparation and evaluation of dried apricot diet jam. Pakistan Journal of Food Science, 3: 21-24.

AOAC, 2012. Official Methods of Analysis. 19 ${ }^{\text {th }}$ edition, Association of Official Analytical Chemists. Gaithersburg, Maryland, USA.

Ayub, M., Zeb, A., Ullah, J., Khattak, M.A.K. 2005. Water activity of dehydrated guava slices sweetened with caloric and non-caloric sweeteners. Science, Technology and Development, 24: 54-59.

Bao, B., Chang, K.C. 1994. Carrot pulp chemical composition, colour and water-holding capacity as affected by blanching. Journal of Food Science, 59: 11591161.

Boyer, J.I.L., Ruilin, R.H. 2004. Apple phytochemicals and their health benefits. Journal of Nutrition, 3: $1-15$.

Campeanu, G., Neata, G., Darjanschi, G. 2009. Chemical composition of the fruits of several apple cultivars growth as biological crop. Notulae Botanicae Horti Agro Botanici Cluj-Napoca, 37: 161-164.

Cecilia, E., Maia, G.A. 2002. Storage stability of cashew apple juice preserved by hot fill and aseptic process. Food Science and Technology, 27: 105-110.

Chaturvedi, A., Sujatha, V., Ramesh, C., Babu, D.J. 2013. Development of shelf stable intermediate moisture carrot shreds using radiation as hurdle technology. International Journal of Food Research, 20: $775-781$.
Chen, B.H., Peng, H.Y., Chen, H.E. 1995. Changes of carotenoids, colour and vitamin A contents during processing of carrot juice. Journal of Agriculture and Food Chemistry, 43: 1912-1918.

Clarke, M.A. 1997. Sugars in food processing. International Journal of Sugar, 99: 14-26.

Desrosier, N.W., Desrosier, J.N. 1978. The Technology of Food Preservation. $4^{\text {th }}$ edition. AVI Publishing Co. Inc. Westport, Connecticut, USA.

Ehsan, E.B., Naeem, Z.P., Javid, A., Nazir, A. 2003. Development, standardization and storage studies on grape fruit apple marmalade. Pakistan Journal of Food Science, 13: 11-15.

Ehsan, E.B., Naeem, Z.P., Ghafoor, A., Bahtti, M.S. 2002. Development, standardization and storage studies on watermelon lemon jam. Pakistan Journal of Food Science, 12: 21-24.

Fu, J.T., Rao, M.A. 2001. Rheology and structure development during gelation of low-methoxyl pectin gels: the effect of sucrose. Food Hydrocolloids, 15: 93-100.

Gimenez, J., Kajda, P., Margomenou, L., Piggot, J.R., Zabetakis, I. 2001. A study on the colour and sensory attributes of high-hydrostatic-pressure jams as compared with traditional jams. Journal of Science of Food and Agriculture, 81: 1228-1234.

Hussain, I., Shakir, I. 2010. Chemical and organoleptic characteristics of jam prepared from indigenous varieties of apricot and apple. World Journal of Dairy and Food Science, 5: 73-78.

Hussain, T. 2001. Food Composition Table For Pakistan. pp. 2-73, Government of Pakistan, Ministry of Planning and Development, Islamabad, Pakistan.

Ilyas, M.B., Ghazanfar, M.U., Khan, M.A., Khan, C.A., Bhatti, M.A.R. 2007. Post-harvest losses in apple and banana during transport and Storage. Pakistan Journal of Agriculture and Science, 44: 534.

Jawaheer, B., Goburdhun, D., Ruggoo, A. 2003. Effect of processing and storage of guava into jam and juice on the ascorbic acid content. Plant Foods for Human Nutrition, 58: 1-12.

Khan, M.U., Qazi, I.M., Ahmed, I., Ullah, S., Khan, A., Jamal, S. 2017. Development and quality evaluation of banana mushroom blended jam. Pakistan Journal of Scientific and Industrial Research, ser. $B$, 60: 11-18.

Khan, R.U., Afridi, S.R., Ilyas, M.M., Sohail, A.H. 2012. Development of strawberry jam and its quality evaluation during storage. Pakistan Journal of Biochemistry and Molecular Biology, 45: 23-25. 
Krinsky, N.I., Johmson, E.J. 2005. Carotenoid actions and their relation to health and diseases. Molecular Aspects of Medicine, 26: 459-516.

Larmond, E. 1977. Laboratory Methods of Sensory Evaluation of Food. 1637 pp., Department of Agriculture, Ottawa Canada.

Lingappa, K., Naik, C. 1997. Wine preparation from carrot. Indian Food Packer, 51: 11-13.

Luciano, J.Q., Isabel, O.S., Robert, S.F., Afonso, M.R., Olga, M.B. 200. Comparative study on antioxidant properties of carrot juice stabilized by high intensity pulsed electric field or heat treatments. Journal of Science of Food and Agriculture, 89: 2636-2642.

Manay, S.N., Shadaksharaswamy, N. 2005. Foods, Facts and Principles, New Age International Publishers, 197 p., New Dehli, India.

Muhammad, A., Durrani, Y., Ayub, M., Zeb, A., Ullah, J. 2009. Organoleptic evaluation of diet jam from apple grown in Swat valley. Sarhad Journal of Agriculture, 25: 81-86.

Rathore, H.A., Masud, T., Sammi, S., Soomro, A.H. 2007. Effect of storage on physicochemical composition and sensory properties of mango variety Dosehari. Pakistan Journal of Nutrition, 6: 143-148.

Riaz, M.N., Mohyuddin, G., Al-Haq, M.I. 1999. Physical, chemical and sensory characteristics of jams made from fresh and frozen strawberries. Pakistan Journal of Arid Agriculture, 2: 51-60.

Samie, A., Abedullah, Ahmed, M., Kouser, S. 2010. Economics of conventional and partial organic farming systems and implications for resource utilization in Punjab (Pakistan). Pakistan Economic and Social Review, 48: 245-260.

Scalbert, A., Williams, G. 2000. Dietary intake and bioavailability of polyphenols.Chocolate: Modern science investigates an ancient medicine. Journal of Nutrition, 130: 2073-2085.

Shah, N.A., Khan, S., Kasi, M.A., Khair, S.M. 2002. Post-harvest and cold storage losses in apple of Baluchistan. Asian Journal of Plant Science,
1: 65-66.

Shah, W., Arsalan, K., Alam, Z., Muhammad, A.K., Falak, N.S., Noor, U.A., Muhammd, A., Said, W., Ali, M., Sher, H.K. 2015. Quality evaluation and preparation of apple and olive fruit blended jam. Global Journal Medical Research: L Nutrition and Food Science, 15: 15-21.

Shakeel, A., Aslam, H.K.W., Shoaib, M., Sikandar, H.A., Ramzan, R. 2013. Effect of various hydrocolloids on cloud stability and nutrition of carrot juice. Journal of Global Innovation in Agriculture and Social Sciences, 1: 22-27.

Shakir, I., Durrani, Y., Hussain, I., Qazi, I.M., Zeb, A. 2007. Physicochemical analysis of apple and pear mixed fruit jam prepared from varieties grown in Azad Jammu and Kashmir. International Journal of Food Safety, 9: 22-24.

Singh, S., Shivhare, U.S., Ahmed, J., Raghavan, G.S.V. 1999. Osmotic concentration kinetics and quality of carrot preserve. Food Research International, 32: 509-514.

Sogi, D.S., Singh, S. 2001. Studies on bitterness development in Kinnow juice, ready-to-serve beverage, squash, jam and candy. Journal of Food Science and Technology, 38: 433-438.

Steel, R.G.D., Torrie, J.H. 1997. Principles and Procedures of Statistics. A Biometrical Approach, $3^{\text {rd }}$ edition, McGraw Hill Book Co., NY, USA.

Suutarinen, J., Honkapaa,K., Heinio, R.L., Autio, K., Mokkila, M. 2000. The effect of different prefreezing treatments on the structure of strawberries before and after jam making. Food Science and Technology, 33: 188-201.

Veltman, R.H., Kho, R.M., Van, A.C.R., Sanders, M.G., Oosterhaven, J. 2000. Ascorbic acid and tissue browning in pears under controlled atmosphere conditions. Post Harvest Biology and Technology, 19: 129-137.

Wang-Qi, Pagan-Jordi, Shi-John. 2002. Pectin from fruits. Functional Foods: Biochemical and Processing Aspects, 2: 263-309. 